\title{
Fuel Properties of Biodiesel from Neem (Azadirachta indica) and Jatropha (Jatropha curcas) Seed Oils using Whole-Cell Biocatalyst
}

\author{
A.O. Mustapha ${ }^{1 *}$, H.A. Bawa ${ }^{2}$, K.S.M.Ali ${ }^{3}$ \\ ${ }^{1,2}$ Department of Chemical, Geological \& Physical Sciences, Kwara State University Malete, \\ PMB 1530, Ilorin, Kwara State, Nigeria. \\ ${ }^{3}$ Deparment of Biology, Faculty of Science, Aljufra University, Aljufra - Libya \\ *Correspondents Author: aliru.mustapha@ kwasu.edu.ng, +2348111020181 \\ Received 02 August 2020; accepted 20 August 2020, published online 28 August 2020
}

\begin{abstract}
Increasing demands coupled with environmental effects of conventional fuels have over time been a source of great concern to seek cost-efficient and environmentally friendly fuels. This work is therefore, to determine the fuel properties of biodiesel from neem (Azadirachta indica) and jatropha (Jatropha curcas) seed oils using whole-cell biocatalyst. Seeds of both neem and jatropha wyere extracted from kernels using a two-staged mechanical process. Whole-cell biocatalyst-mediated trans-esterification of oils into fatty acids methyl esters (FAME) were achieved by the used of isolated strains of Rhizopus orizae. After pretreatment, the percentage yield of oils from seed kernels of neem and jatropha were found to be $29.49 \pm 0.12 \%$ and $34.18 \pm 0.16 \%$ respectively while biodiesel yields from oils of neem and jatropha were $91.20 \pm 0.02 \%$ and $89.90 \pm 0.08 \%$. The neem and jatropha based biodiesels had specific gravities of $0.879 \pm 0.002$ and $0.877 \pm 0.001$, flash points $\left(173 \pm 1.11\right.$ and $\left.135 \pm 1.14^{\circ} \mathrm{C}\right)$; fire points $(205 \pm 0.11$ and $\left(193 \pm 0.01^{\circ} \mathrm{C}\right)$ water and sediments $(0.04 \pm 0.001$ and $0.02 \pm 0.001 \%)$; kinematic viscosity $(2.30 \pm 03$ and $\left.2.10 \pm 0.06 \mathrm{cst} @ 37.8^{\circ} \mathrm{C}\right)$; API gravity $(29.48 \pm 0.37)$ and $(29.85 \pm 1.9)$; free fatty acids $(0.65 \pm 0.03$ and $0.38 \pm 0.04 \% \mathrm{KOH})$; ash contents $(0.03 \pm 0.001$ and $0.01 \pm 0.001 \%)$; iodine number $(79.6 \pm 0.1$ and $20 \pm 0.2$ $\left.\mathrm{mg} \mathrm{I}_{2} / \mathrm{g}\right)$; saponification value $(186.38 \pm 0.17)$ and $(191.75 \pm 0.11 \mathrm{mg}(\mathrm{KOH}) / \mathrm{g})$; and peroxide value $(7.91 \pm 0.09$ and $2.50 \pm 0.03 \mathrm{mg} / \mathrm{kg})$, respectively. Fuel properties of biodiesel compared favorably with American standards for testing materials (ASTM) established limits for biodiesel fuels which showed great potentials in the use of non-food oils coupled with green chemistry in the field of biodiesel research and development.
\end{abstract}

Keywords: fatty acids methyl esters; biodiesel, biocatalyst; neem, jatropa, physicochemical

\section{Introduction}

Over time, man's activities have always centered on the production and utilization of energy, even dated to the stone ages. As time a progress, the energy demand has become exorbitantly increasing. As a result of this, humans are constantly involved in an unending lookout for various forms of energy that will meet up with their demands [1]. For some centuries after the discovery of fossil fuels, its utilization has subsequently skyrocketed to a great extent that now calls for concerns as regards the environmental safety as well as economic impact [2]
Due to a recorded economic and environmental impact emanating from the relentless dependence on fossil fuels, world organizations as well as nations, are resorting to biofuel technology. This is also necessary due to the non-renewable nature of fossil fuels' sources and this has led to research for alternative fuels to interchange conventional petroleum fuel. Today, there are several alternative and renewable fuels in production, of which biodiesel is one. Biodiesel refers to any dieselequivalent fuel made up of renewable biological materials like vegetable oils or animal fats [3]. Biodiesels are non-toxic biodegradable fuels which can be produced from animals' oils and fats as well as used or recycled oils and fats. Biodiesel is a clean-burning fuel that varies in 
colour between golden and dark brown depending on the oil/fat source [4]. Biodiesel, like petroleum diesel is designed to be used in compression-ignition internal combustion engines, also known as "diesel engines". The diesel engine was invented by Dr. Rudolph Diesel and was powered by peanut oil [5]. Consequently, it became established that the high temperature of a diesel engine can run on various forms of vegetable [6]. Currently, dieselpowered vehicles represent over $30 \%$ of the cars sold in Europe, the United States as well as Asia, and it is being predicted that these figures will double in coming decades [7].

As an alternative to petroleum diesel in the transportation sector, biodiesel can quickly become a crucial solution for environmental and economic problems for four significant reasons. First, it does not require any engine modifications; second it reduces greenhouse gas (GHG) emission substantially; third, its sources are renewable and easily processed, and finally it also improves the lubricity of the engines. These factors have made biodiesel usage more versatile and attractive, to ensure energy security, environmental sustainability and also to boost rural development by shifting of power from petroleum to agro-based industry.

Considerable studies have been done on vegetable oils to biodiesel using acid [8], base [9], enzyme catalyst and two-step based catalysis [10], but all these catalyst are costintensive. Also, a wealth of literatures exists on transesterification of triglycerides using calcium-rich materials like eggshell [11], snail shell [12], shellfish [13], for biodiesel production. However, there are relatively few studies in the literature on the conversion of seed oils to biodiesel using whole-cell biocatalyst.

Owing to the above, partial replacement of diesel by biofuel can substitute the petroleum resources and abate the radical climate change caused by automotive pollutants. The motivation for this study was predicated on the economic and environmental advantage of biofuels over fossil fuels. It is also pertinent to note that the use of oils of low economic importance and nonedible lipids such as neem and jatropha seeds oils was employed. Further, environmental consideration was deployed in the methodology. Specifically, green chemistry was employed in the extraction of oil from seeds as well as the transesterification reaction of the triglycerides into fatty acid methyl esters (biodiesels).

\section{Materials and Methods}

\subsection{Materials and Reagents}

Analytical grade reagents from certified manufacturer were procured from registered chemical distributors within Nigeria. The reagents include sodium chloride $(\mathrm{NaCl})$, sodium hydroxide $(\mathrm{NaOH})$, activated charcoal, potassium hydroxide, peptone, potatoes dextrose agar (PDA) and potatoes dextrose broth (PDB), magnesium sulphate $\left(\mathrm{MgSO}_{4}\right)$ and magnesium chloride $\left(\mathrm{MgCl}_{2}\right)$, sodium nitrate $\left(\mathrm{NaNO}_{3}\right)$, potassium hydrogen phosphate $\left(\mathrm{KH}_{2} \mathrm{PO}_{4}\right)$, iron sulphate $\left(\mathrm{FeSO}_{4}\right)$, distilled deionized water, standard phosphate $\mathrm{pH}$ Buffer Tablets, methanol, among others. Strains of microorganisms (rizopus oryzae) for biocatalysis were collected from cultured apple fruits.

Fresh seeds of Jatropha were purchased from a farmer in Kasuwan Monday, Kajuru Local Government Area of Kaduna state. In contrast the neem seeds were handpicked from the bottom of neem trees in Hayin Dan Mani, Igabi Local Government Area of Kaduna State. The seeds were air-dried and stored for further analysis.

\subsection{Materials and reagent preparation}

Materials were prepared following standard procedures as recorded [14] with some adjustments. Procedures conducted on seeds included extraction of oils from seeds, refining processes, pre-treatment and transesterification of oils using $S$. oryzae as whole-cell biocatalyst followed by the determination of physicochemical (fuel) properties of biodiesel [15]

\subsection{Inoculum preparation for biocatalysis}

Samples of spoilt green apple fruits were collected from a fruits vendor in Effurun, Delta State. The fruits were then cut into smaller 
pieces that were previously sterilized in a $1 \%$ hypochlorite for 2 minutes. This was transferred aseptically to potatoes dextrose agar plates and incubated at room temperature for 120 hours [16]

\subsection{Transesterification Reaction}

The purified seed oils (Figure 1) were transesterified using $S$. oryzae as whole cell biocatalyst as recorded [14] with some adjustments and the percentage yield of each biodiesel obtained was determined [15]

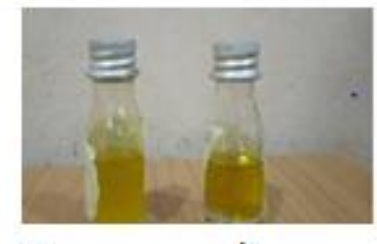

a

b

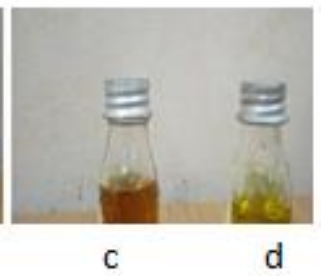

Figure 1: Samples of (a) neem oil (b) biodiesel from neem (c) jatropha oil (d) biodiesel from jatropa

\subsection{Physicochemical analysis and profiling of oil and biodiesel}

Physicochemical properties of neem and jatropha oils were carried out according to Official Methods of the Association of Official Analytical Chemists (AOAC, $[17,18]$ standards with some modifications. This is necessary to determine its suitability for use in the production of biodiesel. The parameters determined included specific gravity flash points fire points, water and sediments, kinematic viscosity API, gravity, free fatty acids, ash contents, iodine number, saponification value and peroxide value $[19,20]$

\section{Results and Discussion}

\subsection{Oil and biodiesel yields}

To maximize the production process, it would be necessary to incorporate the production of oils from a single mechanical plant. Such plant should include processors involved in seed dehusking, kernel separator as well as kernel crushers. This should minimize production time and reduce human error. Table 1 presents the data for oil yields of neem and jatropha from two-staged mechanical expression process described above [29]. The percentage yields of neem and jatropha oils from the kernel are $29.41 \pm 0.12 \%$ and $34.18 \pm 0.16 \%$, respectively. The extractable oils from jatropha fall below the ASTM (2016) range of 46-55\% with an average of $34.4 \%$. Similarly, the extractable oil from neem was in the range of $25-45 \%$ [21]

Table 1 Percentage yields

\begin{tabular}{lcl}
\hline Seed type & Neem oil & Jatropha oil* \\
\hline Avg. Mass of seed $(\mathrm{g})$ & $1000 \pm 0.91$ & $1000 \pm 1.02$ \\
Mass of Kernel $(\mathrm{g})$ & $531.25 \pm 1.16$ & $581.27 \pm 1.25$ \\
Mass of husks $(\mathrm{g})$ & $468.75 \pm 1.24$ & $418.73 \pm 1.17$ \\
Percentage kernel $(\%)$ & $53.13 \pm 0.18$ & $58.13 \pm 0.23$ \\
Percentage husks $(\%)$ & $46.88 \pm 0.23$ & $41.87 \pm 0.19$ \\
Mass of oil (g) & $156.25 \pm 0.99$ & $198.35 \pm 0.92$ \\
Percentage yield (\%) & $29.41 \pm 0.12$ & $34.18 \pm 0.16$ \\
\hline *Values are mean \pm standard & deviation of \\
triplicate determinations &
\end{tabular}

Olaoluwa et al. [15] recorded a biodiesel percentage yield of 79 to $86 \%$, with biodiesel produced by an organic catalyst showing about $80 \%$. In a similar development, a varying percentage yield as they experimented various condition for biodiesel production. Guang and Thomas [14] examined the use of whole-cell biocatalysts to produced biodiesel at room temperature. Their results indicate that the whole-cell biocatalyst can produce about a $90 \%$ yield of FAME from virgin oil, with an increased yield with time. It becomes pertinent to note that from Table 2, biodiesel produced from both neem and jatropha were of comparatively high yields with a percentage yield of $91.20 \pm 0.02 \%$ and $89.90 \pm 0.08 \%$ respectively. Owing to the high content of free fatty acids in jatropha and neem, 
it is easy to cause a saponification phenomenon when $\mathrm{NaOH}$ is directly used as a catalyst for the production of biodiesel, thus reducing the conversion rate of oils [22] Therefore the use of biocatalyst preceeded by the various stages of pretreatment effectively increased yield of biodiesel as well as eliminates chemical interferences.

Table 2 Percentage yield of biodiesels

\begin{tabular}{lll}
\hline Measurements & Neem oil* & $\begin{array}{l}\text { Jathropha } \\
\text { oil } *\end{array}$ \\
\hline Pretreated oil $(\mathrm{ml})$ & $11.20 \pm 0.09$ & $10.80 \pm 0.11$ \\
Mass of pretreated oil $(\mathrm{g})$ & $10 \pm 0.03$ & $10 \pm 0.01$ \\
Mass of biodiesel $(\mathrm{g})$ & $9.12 \pm 0.07$ & $8.99 \pm 0.04$ \\
Yield of biodiesel $(\%)$ & $91.20 \pm 0.02$ & $89.90 \pm 0.08$ \\
\hline$*$ Values are mean \pm standard & deviation of \\
triplicate determinations
\end{tabular}

\subsection{Physicochemical properties of crude oils}

The physicochemical properties of extracted oils of neem and jathropha are presented in Table 3. The flash points for neem and jathropha were $227.00 \pm 1.09$ and $195.00 \pm 1.21^{\circ} \mathrm{C}$, respectively. The flash point of a volatile material is the lowest temperature at which its vapors ignite if given an ignition source. Most common combustible and flammable liquids have autoignition temperatures in the range of $300^{\circ} \mathrm{C}$ to $550^{\circ} \mathrm{C}$. For vegetable oils, neither flash point nor fire point depends directly on the ignition source temperature, but ignition source temperature is far higher than either the flash or fire point. The flash point is a very important concept in fire investigation and fire protection. Kinematic viscosity of neem and jatropha was found to be $8.00 \pm 1.01$ and $7.00 \pm 1.03\left(\mathrm{cst} @ 37.8^{\circ} \mathrm{C}\right.$ ) respectively. Similarly, other physicochemical properties for neem and jatropha seed oils are represented in Table 3.

\section{Table 3 Physicochemical properties of extracted virgin oils}

\begin{tabular}{|c|c|c|c|}
\hline Property & $\begin{array}{l}\text { ASTM } \\
\text { Method }\end{array}$ & $\begin{array}{l}\text { Neem } \\
\text { FAME B100* }\end{array}$ & $\begin{array}{l}\text { Jatropha } \\
\text { FAME B100* }\end{array}$ \\
\hline Flash Point, ${ }^{\circ} \mathrm{C}$ & D93 & $173 \pm 1.11$ & $135 \pm 1.14$ \\
\hline Fire point, ${ }^{\circ} \mathrm{C}$ & D92 & $205 \pm 0.11$ & $193 \pm 0.01$ \\
\hline Water, \% & D2709 & $0.04 \pm 0.001$ & $0.02 \pm 0.001$ \\
\hline Kinematic & D445 & $2.30 \pm 0.03$ & $2.10 \pm 0.06$ \\
\hline $\begin{array}{l}\text { Viscosity, } \\
\text { cst @ } 37.8^{\circ} \mathrm{C}\end{array}$ & D1298 & $0.879 \pm 0.002$ & $0.877 \pm 0.001$ \\
\hline $\begin{array}{l}\text { Specific gravity, } \\
\text { @ 60/60 } \mathrm{F}\end{array}$ & D287 & $29.48 \pm 0.37$ & $29.85 \pm 1.90$ \\
\hline API Gravity & D5555 & $0.65 \pm 0.03$ & $0.38 \pm 0.04$ \\
\hline Free Fatty Acid, \% & D482 & $0.03 \pm 0.001$ & $0.01 \pm 0.001$ \\
\hline Ash Content, \% & D5554 & $103 \pm 2.23$ & $96 \pm 1.99$ \\
\hline $\begin{array}{l}\text { Iodine Value, } \\
\mathrm{mg} \mathrm{I}_{2} / \mathrm{g}\end{array}$ & Wijs & $79.6 \pm 0.1$ & $20 \pm 0.2$ \\
\hline $\begin{array}{l}\text { Saponification } \\
\text { Value, mg } \\
(\mathrm{KOH}) / \mathrm{g}\end{array}$ & D94 & $109 \pm 1.77$ & $189.12 \pm 0.08$ \\
\hline $\begin{array}{l}\text { Peroxide Value, } \\
\mathrm{mg} / \mathrm{kg}\end{array}$ & D1832 & $0.63 \pm 0.01$ & $0.76 \pm 0.03$ \\
\hline
\end{tabular}

The significance of physicochemical properties of neem and jatropha seed oil is to determine their suitability for use in the production of biodiesel. Physicochemical parameters are also necessary to determine the nutritional value or otherwise of the seed oils. Akubugwo et al. [23] conducted a comparative analysis of vegetable oils for domestic and industrial purposes.

\subsection{Fuel properties of biodiesel}

Biodiesels have significant potential for use as an alternative fuel in compression-ignition diesel engines [24]. For this to be materialized, biodiesel must comply with existing standards [21]. Fuel properties are an indication of whether the given biodiesel would be suitable or not for the performance, lifespan and emission of the compression-ignition engine ([25]. Fuel properties of the biodiesel synthesized were found to exhibit appreciable fuel properties. (Table 4) 
Table 4: Fuel properties of biodiesel

\begin{tabular}{|c|c|c|c|}
\hline Fuel properties & $\begin{array}{l}\text { ASTM } \\
\text { Method }\end{array}$ & Neem oil* & Jatropha oil* \\
\hline Flash Point, ${ }^{\circ} \mathrm{C}$ & D93 & $227.00 \pm 1.09$ & $195.00 \pm 1.21$ \\
\hline Fire point, ${ }^{\circ} \mathrm{C}$ & D92 & $249.00 \pm 2.91$ & $150.05 \pm 0.13$ \\
\hline Water, \% & D2709 & $0.30 \pm 0.01$ & $0.6 \pm 0.01$ \\
\hline $\begin{array}{l}\text { Kinematic Viscosity, } \\
\text { cst @ } 37.8^{\circ} \mathrm{C}\end{array}$ & D445 & $8.00 \pm 1.01$ & $7.00 \pm 1.03$ \\
\hline $\begin{array}{l}\text { Specific gravity, } \\
\text { @ 60/60 } \mathrm{F}\end{array}$ & D1298 & $0.925 \pm 0.001$ & $0.905 \pm 0.001$ \\
\hline API Gravity & D287 & $21.47 \pm 0.16$ & $24.85 \pm 0.17$ \\
\hline Free Fatty Acid, \% & D5555 & $0.17 \pm 0.01$ & $0.49 \pm 0.01$ \\
\hline Ash Content, \% & D482 & $0.21 \pm 0.07$ & $0.25 \pm 0.04$ \\
\hline Iodine Value, $\mathrm{mg} \mathrm{I}_{2} / \mathrm{g}$ & Wijs & $79.6 \pm 0.1$ & $20 \pm 0.2$ \\
\hline $\begin{array}{l}\text { Saponification Value, } \\
\mathrm{mg}(\mathrm{KOH}) / \mathrm{g}\end{array}$ & D94 & $186.38 \pm 0.17$ & $191.75 \pm 0.11$ \\
\hline $\begin{array}{l}\text { Peroxide Value, } \\
\mathrm{mg} / \mathrm{kg}\end{array}$ & D1832 & $7.91 \pm 0.09$ & $2.50 \pm 0.03$ \\
\hline
\end{tabular}

*Values are mean \pm standard deviation o triplicate determinations

Diesel fuels have flash points range of $52-96^{\circ} \mathrm{C}$, biodiesel flash points are often higher, with a minimum limit of $100^{\circ} \mathrm{C}$ [24]. The flash points for neem and jatropha (Table 4) are $173 \pm 1.11$ and $135 \pm 1.14$ respectively; while the fire points for neem and jatropha are $205 \pm 0.11$ and $193 \pm 0.01^{\circ} \mathrm{C}$ respectively. Both flash and fire points are inter-related, but fire points are significantly higher than flash point for any given sample. It was Diesel fuels have flash points range of $52-96^{\circ} \mathrm{C}$, biodiesel flash points are often higher, with a minimum limit of $100^{\circ} \mathrm{C}$ [24]. The flash points for neem and jatropha (Table 4) are $173 \pm 1.11$ and $135 \pm 1.14$ respectively; while the fire points for neem and jatropha are $205 \pm 0.11$ and $193 \pm 0.01^{\circ} \mathrm{C}$ respectively. Both flash and fire points are interrelated, but fire points are significantly higher than flash point for any given sample. It was found that the flash and fire points for neem biodiesel are considerably higher than those of jatropha. Interestingly, both values fall within an acceptable range for autoignition engines and safety of usage. Diesels and biodiesels are suitable for use in a compression-ignition engine. Here, the air is compressed until it heats above the auto ignition temperature of the fuel, which is then injected as a high-pressure spray, keeping the fuel-air mix within flammable limits. A diesel-fueled engine has no ignition source (such as the spark plugs in a gasoline engine), so diesel fuel must have a high flash point and a low auto ignition temperature (The Engineering Toolbox 2020).

From Table 4, the water and sediment content of FAME from neem and jathropha were found to be $0.04 \pm 0.001$ and $0.02 \pm 0.001 \%$ respectively. These values are considerably lower than their corresponding oils (Table 3), and their values are suitable for diesel engines. Water and sediment is a significant parameter because higher values can cause corrosion of equipment and problems in processing. A determination of water and sediment content is required to measure accurately net volumes of actual fuel oil in sales, taxation, exchanges, and custody transfers (ASTM 2016).

It could also be observed in Table 4, that values for kinematic viscosity of biodiesels from neem and jatropha dropped considerably from their respective seed oil values (Table 3 ). This is important to the lifespan of fuel pumps in an automobile as well as the fluidity of the fuels. The fuel which is too highly viscous can cause damage in the fuel pump due to higher pressure. Like Kinematic viscosity, specific gravity and API gravity have been useful tools in elucidating fuel properties. In Table 4, the specific gravity of neem and jatropha were found to be $0.879 \pm 0.002$ and $0.877 \pm 0.001 @ 60 / 60^{\circ} \mathrm{F}$ respectively. Similarly, the API gravities of neem and jatropha were found to be $29.48 \pm 0.37$ and $29.85 \pm 1.90$ respectively. All values are close but appear distinct and lower than the values obtained from their respective oils. Further, the standard limits for specific and API gravities are $0.85-0.88\left(@ 60 / 60^{\circ} \mathrm{F}\right)$ and $29-35$ respectively [19]. Observably, values for specific and API gravities of neem and jatropha were found to fall within the range. Denser biodiesel has higher energy content and results in better mileage and increased power. Since the fatty acid content dictates the specific gravity, a denser vegetable oil processes into a denser biodiesel 
Low ash content and carbon residue contents produced lower deposition of carbon on engine parts and increases the engine life [25]. The ash content of synthesized biodiesels were found to be considerably low, but higher than those of fossil diesels. Specifically, the ash contents of neem and jathropha were found to be $0.03 \pm 0.001$ and $0.01 \pm 0.001$ respectively. These values are much lower than those obtained from their respective virgin oils. The discrepancy may not be unconnected to processing such as pretreatment as well as biocatalyzed transesterification conducted on the seed oils.

Iodine numbers are often used to determine the amount of unsaturation in fatty acids. This unsaturation is in the form of double bonds which react with iodine compounds [26]. The short-chain fatty acids found in oils have a high saponification value because they have a relatively higher number of carboxylic functional groups per unit mass of the oil. Similarly, peroxide value, the of peroxide in oil, fat or biodiesel, is useful for assessing the extent to which spoilage has advanced [27]. The three parameters (peroxide, iodine and saponification values) are key parameters in determining the lifespan of the biodiesel. As shown in Table 4, the iodine values for neem and jatropha are $103 \pm 2.23$ and $96 \pm 1.99 \mathrm{mg} \mathrm{I}_{2} / \mathrm{g}$

respectively. These values indicate the presence of unsaturated fatty acid chains in biodiesel. Interestingly, the peroxide values of neem and jatropha FAME as seen in Table 4 are considerably low, indicating low rancidity of the FAME. Though the peroxide value of jatropha biodiesel is low $(0.76 \pm 0.03 \mathrm{mg} / \mathrm{kg})$, it is sufficiently higher than that of neem $(0.63 \pm 0.01 \mathrm{mg} / \mathrm{kg})$. A careful observation of the saponification values for neem biodiesel (Table 4) when compared to the oil (Table 3), there is a drastic drop in saponification value from the oil $(186.38 \pm 0.17 \mathrm{mg}(\mathrm{KOH}) / \mathrm{g})$ to the biodiesel $(109 \pm 1.77 \mathrm{mg}(\mathrm{KOH}) / \mathrm{g})$ with about 77 units. Surprisingly, this was not the same in the case of jatropha, whose saponification value only dropped from the oil $(191.75 \pm 0.11 \mathrm{mg}(\mathrm{KOH}) / \mathrm{g})$ to the biodiesel $(189.12 \pm 0.08 \mathrm{mg}(\mathrm{KOH}) / \mathrm{g})$ with only about 2 units. According to Akbar et al
(2009), the saponification value for biodiesel was $244.74 \mathrm{mg} \mathrm{KOH} \mathrm{g}^{-1}$ while that for jathropa oil was $193.55 \mathrm{mg} \mathrm{KOH} \mathrm{g}^{-1}$. The high saponification values obtained indicate the presence of a high percentage of fatty acids which might lead to soap formation [28]. Hence the separation of products will be exceedingly difficult. This could account for the low yield of biodiesel product as observed in Table 2 [4].

\section{Conclusion}

The fuel properties of biodiesel from neem (Azadirachta indica) and jatropha (Jatropha curcas) seed oils using wholecell biocatalyst were thus conducted, with a percentage yield of oils from seed kernels of neem and jatropha being $29.49 \%$ and $34.18 \%$ respectively. The percentage yield of biodiesel from oils of neem and jatropha was $91.2 \%$ and $89.9 \%$. Fuel properties of both neem and jatropha appear to be appreciable when compared to standard limits. Therefore, neem and jatropha oils appear promising as feedstock for biodiesel production, and can be partially substituted for petro-diesel blends under most operating conditions, regarding performance parameters with little or no modifications to the engine. The results obtained thus showed great potentials in the use of non-food oils coupled with green chemistry in the field of biodiesel research and development.

\section{Conflict of Interest}

The authors declare that there is no conflict of interest.

\section{Reference}

1. E.S. Rahadianti, Yerizam and Martha (2018), "Biodiesel Production from Waste Cooking Oil" Indones. J. Fundam. Appl. Chem., 3(3), 2018, 77-82. DOI: $10.24845 /$ ijfac.v3.i3.77 77

2. Jatinder Kataria, S.K.Mohapatra, K.Kundu (2019). Biodiesel production from waste cooking oil using heterogeneous catalysts and its 
operational characteristics on variable compression ratio CI engine. Journal of the Energy Institute. 92, (2), 275-287

3. B. Thangaraj, P. Raj, B. Muniyandi, S. Ranganathan and L. Lin (2019), Catalysis in biodiesel production-a review, Clean Energy, 3, (1): $2-23$

4. C.N. Ibeto, A. Ofoefule, A. Ofoefule and K. Agbo (2011), A Global Overview of Biomass Potentials for Bioethanol Production: $A$ Renewable Alternative Fuel. Trends in Applied Sciences Research 6(5):410-425

5. B. Ghobadian, H. Rahimi, H. RahimiAli, N. Nikbakht, A.M. Nikbakht and T.F. Yusaf. (2009), Diesel engine performance and exhaust emission analysis using waste cooking biodiesel fuel with an artificial neural network. Renewable Energy 34(4):976-982

6. A.S. Silitonga, A.E. Atabania, T.M.I. Mahliaa, H.H. Masjukia, I.A. Badruddina, and S. Mekhilefe (2011), A review on prospect of Jatropha curcas for biodiesel in Indonesia. Renewable and Sustainable Energy Reviews 15, 3733-3756

7. S. Zheng, M. Kates, M.A. Dubé and D.D. McLean (2006), Acid-catalyzed production of biodiesel from waste frying oil", Biomass Bioenergy, 30: 267-272.

8. P. P. Felizardo, M.S. Baptista, J.C. Uva, Menezes and M.J.N. Correia (2007), Monitoring biodiesel fuel quality by near infrared spectroscopy. Journal Near Infrared Spectroscopy, 15: 97-105.

9. G. Chen, M. Ying and W. Li (2006), Enzymatic conversion of waste cooking oils into alternative fuel-biodiesel. Applied Biochemistry. Biotechnology, 129-132, 2006.

10. Y. Wang, S.Y. Ou, P.Z. Liu, and Z.S. Zhang (2007), Preparation of biodiesel from waste cooking oil via two- step catalyzed process. Energy Conversion Management, 48: 184-188, 2007
11. N. Viriya-Empikul, P. Krasae, W. Nualpaeng, B. Yoosuk and K. Faungnawakij (2012), Biodiesel production over Ca-based solid catalysts derived from industrial wastes, Fuel, 92 (1), 239-244

12. J. Boro, A.J. Thakurb, D. Dekaa (2011), Solid oxide derived from waste shells of Turbonilla striatula as a renewable catalyst for biodiesel production. Fuel Processing Technology, 92 (10): 2061-2067

13. R. Rezaei, M. Mohadesi and G.R. Moradi (2013), Optimization of biodiesel production using waste mussel shell catalyst, Fuel, 109: 534-541, 2013.

14. J. Guang and B. J. Thomas (2010), Wholecell Biocatalysts for Producing Biodiesel from Waste Greases. Champaign, IL: Illinois Sustainable Technology Center. 2010-03. http://hdl.handle.net/2142/15218

15a. R.O. Olaoluwa, S.A. Abolanle, A.O.O. John, M.O. Efere, S.O. Olatunji, M.S. Adedayo, A.A. Muib and M.A. Oyedare (2017), Refining, Toxicology Study and Biodiesel Potentials of Used Vegetable Oils. American Journal of Food Science and Technology, 5 (3),78-88 DOI:10.12691/ajfst-5-3-2

16. J. Samuel, P. Coulibaly and A.R. Metcalfe (2011), Identification of rainfall-runoff model for improved baseflow estimation in ungauged basins.Retrieved:

https://onlinelibrary.wiley.com/doi/abs/10.1002/ Hyp. 8133 16/07/2020

17. AOAC. (1990). Official Methods of the Association of Official Analytical Chemists. Official methods of analysis of the AOAC, 15th ed. Methods 932.06, 925.09, 985.29, 923.03. Association of Official Analytical Chemists. Arlington, VA, USA.

18. AOAC (2012), Official methods of analysis, Association of official analytical chemist 19th edition, Washington D.C., USA. 
19. American Society for Testing Materials (ASTM) 2003. ASTM Standards Methods: ASTM pub; Philadelphia.

20. ASTM (2016). Standard Test Methods. Developed by Sub-committee: D02.02. Book of Standards Volume: 05.01

21. O. Awogbemi, E. I. Onuh and F. L. Inambao (2019). "Comparative study of properties and fatty acid composition of some neat vegetable oils and waste cooking oils" International Journal of Low-Carbon Technologies, 14, 417425

22. Y. Cheng-Yuan, F. Zhen, L. Bo and L. Yunfeng (2010), Review and prospects of Jatropha biodiesel industry in China. Renewable and Sustainable Energy Reviews, 16(4): 2178-2190

23. I.E. Akubugwo, V. Chinyere, A.E. Ugbogu (2008), Comparative Studies on Oil from Some Common Plant Seeds in Nigeria. Pakistan Journal of Nutrition 7(4): 570-573.

24. K. Bencheikh, A.E. Atabani, S. Shobana, M.N. Mohammed, G. Uğuz, O. Arpa, G. Kumar, A. Ayanoğlu and A. Bokhari (2019), Fuels properties, characterizations and engine and emission performance analyses of ternary waste cooking oil biodiesel-diesel-propanol blends. Sustainable Energy Technologies and Assessments, 35

25. B. Karmakar, H.D. Sumit and H. Gopinath (2018), Optimization of biodiesel production from castor oil by Taguchi design. Journal of Environmental Chemical Engineering, 6 (2): 2684-2695

26. FoodLab (2020). Determination of Iodine Value in Palm Oil. Retrieved: https://www.cdrfoodlab.com/foods-beveragesanalysis/iodine-value-palm-oil/ 16/07/2020

27. S. Chakrabarty, S.R.P. Primandari, A.K.M. Aminul Islam, Z. Yaakob and S. Yaakob (2018), Jatropha Curcas L. Biomass Waste and Its Utilization. In book: Advances in Biofuels
28. O.O. Oluwaniyi and O.O. Dosumu (2009), Preliminary Studies on the effect of processing methods on the quality of three commonly consumed marine fishes in Nigeria. Biokemistri, 21: 1-7.

29. A.O. Arișanu (2013), Mechanical continuous oil expression from oilseeds: oil yield and press capacity. 5th International Conference "Computational Mechanics and Virtual Engineering" COMEC 2013 24-25 October 2013, Braşov, Romania 